\title{
The Ephesian elders come to Miletus: An Annaliste reading of Acts 20:15-18a
}

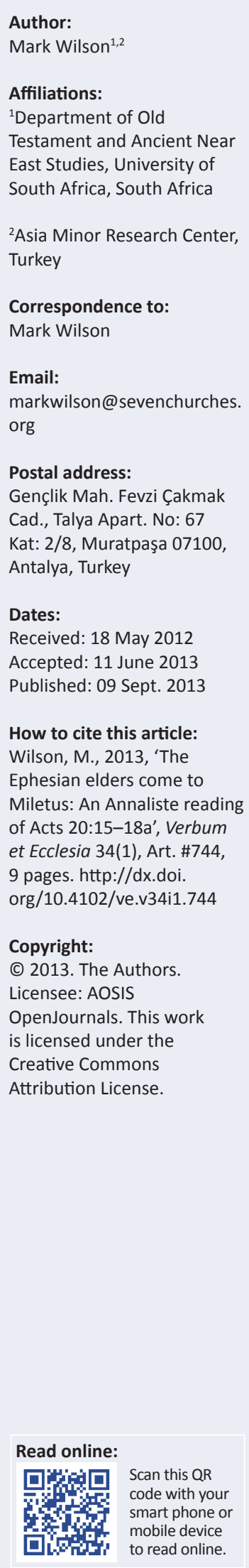

In his recent study on Ionia, A. Greaves adopts an Annaliste approach following the pioneering work of Fernand Braudel. Greaves attempts to move beyond a text-based understanding of sites and events by also considering the related landscape and geographical data. This study adopts Greaves' methodology in examining a text in Acts related to the Ionian cities of Ephesus and Miletus. Acts 20:15-18a records that Paul bypassed Ephesus, but later summoned the Ephesian elders to meet him in Miletus. This summons sets up one of Paul's most important speeches and the only one in Acts delivered to a Christian audience. This study will examine the landscape and geography related to this stage of Paul's third journey as well as the journey of the Ephesian elders to Miletus. It will also look at how recently published Bible atlases have incorrectly illustrated this segment of Paul's journeys. An Annaliste reading will bring fresh insights into Paul's travel habits and his decision making related to ministry as depicted in this pericope in Acts.

\section{Introduction}

This article ${ }^{1}$ attempts to elucidate a text in the book of Acts - the visit of the Ephesian elders to Miletus ${ }^{2}$ during Paul's third journey - by way of an Annaliste reading. Discussed first is the methodology underlying this reading, which is drawn from a recent book by A. Greaves on Ionia. The primary focus is to examine the geography and history related to Paul's sea journey, the journey of the elders, and the sacred role of Miletus as a pilgrimage city. The study also reveals an important geographical lacuna in the maps of western Asia Minor found in all atlases of the Bible. The conclusion reviews the insights gained from this reading for understanding the pericope in Acts.

\section{Methodology}

In his recent book, The land of Ionia, Greaves (2010) adopts an Annaliste approach to his study of archaic Ionia. Greaves builds upon the ideas of Braudel as articulated in the latter's classic 1972 study The Mediterranean and the Mediterranean world in the age of Philip II. In this volume, Braudel (1972) presents time according to three scales: (1) long-term geographic time (géohistoire or longue durée), concerned with people in relation to their environment, (2) medium time-scale (conjoncture), concerned with social history epitomised in 'economic systems, states, societies, civilisations and empire' (1972:21) and (3) short-term microhistory (l'histoire événementielle), which is episodic and lacking in pattern. ${ }^{3}$ From this perspective, Braudel argued that 'historical events achieve significance only when evaluated in spatially extensive, diachronic contexts' (as quoted in Knapp 1992:6).

In his study, Greaves builds upon this perspective by adopting a methodology that articulates five points: (1) landscape and environment are primary backgrounds, (2) human agency within environmental constraints must be recognised to avoid geographical determinism, ${ }^{4}$ (3) literature no longer provides the ultimate point of reference against which hypotheses are tested, (4) classical archaeology is no longer a treasure hunt wherein the clues are provided entirely by the texts and (5) textual and epigraphic sources must be balanced with archaeological and geographical ones (this is a summary of Greaves' [2010: 39-44] discussion). Greaves illustrates this using a pyramid graph (Figure 1). At the bottom he places landscape and environment; other themes and ideas are then built upon this.

\footnotetext{
1.This article was first presented in an earlier draft at the Book of Acts Section of the Society of Biblical Literature, San Francisco, November 2011.

2.For this article I am using the Latin spelling Miletus as used in the English translations of Acts rather than the Greek spelling Miletos used by Greaves and other scholars.

3.Lambrianides and Spencer (2007:1-3) in their study of a similar river delta on the Aegean Coast, the Madra, also engaged with Braudel's three famous time-scales.

4.An emphasis on a deterministic environment and a neglect of human agency has been perceived as a weakness of Braudel's model; see
} Lambrianides and Spencer (2007:2) and Knapp (1992:7). 
He calls this a 'bottom-up' approach and objects to the fact that traditional studies begin at the apex of the triangle by examining the literary and epigraphic output of the elite. Other evidence, archaeological and otherwise, is then fitted into the metanarrative or 'story' constructed from the literary sources. Whilst Greaves' approach is not necessarily sequential and an overlap exists amongst points $3-5$, his point that landscape and environment are primary backgrounds and that literary texts should be supplemental is a critical observation influencing the methodology of this study.

The historian J. Ma (1999) reiterates the importance of geographical background, stating that:

$[m]$ uch more instructive for our purposes than 'ancient ruins', the land still allows us to study ancient sites-specific places in their relation with the geography. Western Asia Minor ... still survives as a physical entity, which can be studied on maps and in the accounts of earlier travellers, or by travel to modern Turkey, as long as attention is given not just to the cities, but also to routes, plains, mountains and the ways through them. (p. 17)

Ma's closing words emphasise that bodies of water and the passages across them must also be considered. Greaves (2010:1) makes a comment closely related to that of Ma (1999): 'An understanding of the physical environment is not just useful but essential when one is trying to understand any ancient city.'

Although biblical scholars are not the primary object of Greaves' critique, his points nevertheless strike a chord with this guild as well. As biblical scholars seek to interpret texts such as Acts, their exegesis often starts at the apex of the triangle. In seeking to adapt Greaves' methodology to biblical studies by implementing them in this study, several preliminary observations can be made: (1) landscape and environment area significant background to a biblical text, (2) human agency, in the form of the early Christians, is important as it acts within this landscape and environment, (3) other biblical texts may not provide the ultimate point of reference for how a text in question is interpreted, (4) exegesis must not be a treasure hunt wherein the clues are provided entirely by other texts and (5) literary and epigraphic sources must be balanced with geographical and archaeological ones.

With these methodological guidelines established, let us now attempt an Annaliste reading of the visit of the Ephesian elders to Paul in Miletus found in Acts 20:15-18a. The Greek text and my translation are below. These verses set up Paul's important speech that follows in verses $18 b-35$ :

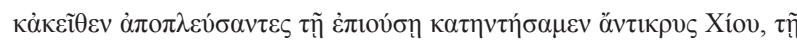

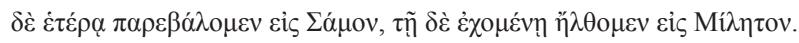

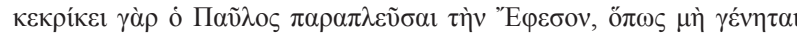

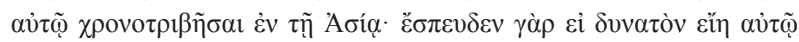

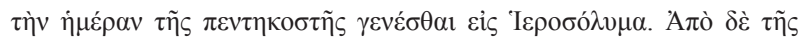

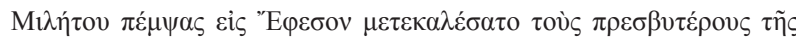

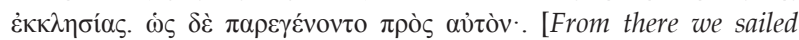
on the following day and arrived offshore of Chios. The next day we approached Samos, and the day after we came to Miletus. For Paul had

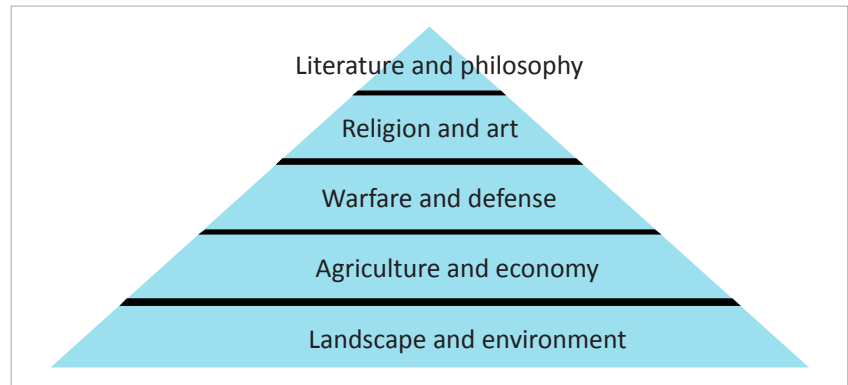

Source: Greaves, A., 2010, The land of lonia: Society and economy in the archaic period, Wiley Blackwell, West Sussex

FIGURE 1: Greaves' 'bottom-up' approach.

decided to sail past Ephesus, so that he might not lose time in Asia. For he was hurrying to be in Jerusalem, if possible, on the day of Pentecost. From Miletus he sent a \{messenger\} to Ephesus to summon the elders of the church. And when they came to him ...] (Acts 20:18b-35, [author's own translation])

\section{Around Mycale to Trogyllium}

After departing Chios, Paul's ship crossed over to Samos (20:15). Paul decided to bypass Ephesus because of his unwillingness to be delayed in Asia and his desire to reach Jerusalem by Pentecost (Ac 20:16). ${ }^{5}$ Bible atlases are split regarding the ship's route, ${ }^{6}$ whether it went west of Samos through open seas or followed the somewhat longer route along the coastline of Asia Minor. ${ }^{7}$ Three factors favour the coastal route: (1) the open sea is more risky in the event of a storm, (2) coasting vessels tend to stay close to ports and (3) the port of Samos (modern Pithagorio) was on the southeastern corner of the island toward Asia Minor. The inside route would be therefore the safest and quickest. ${ }^{8}$ Ahead of Paul's ship was a wall of stone called the Mycale Mountains (Samsun Dağ1) looming some 610 m overhead, with their highest peak soaring to $1237 \mathrm{~m}$. In 479 BCE Mycale was the site of a great battle in which the Persians were defeated by the Greeks. Paul's ship would have been forced to turn westward to sail around Mycale, and it then entered the narrow strait of $1300 \mathrm{~m}$ wide that separated Asia Minor from the island of Samos (Wilson 2010:326). After passing through this strait, the ship probably stopped for food and water at Samos's main port. After reprovisioning, the ship next attempted to sail around Mycale.

5.As Walton (2007:53) astutely observes, two motifs dominate the description of the third journey - the focus on Jerusalem and a sense of divine restraint.

6.For example, the Moody atlas of the Bible (Beitzel 2009:261 [Map 112]); the IVP atlas of Bible history (Lawrence 2006:161); the Crossway ESV Bible atlas (Currid \& Barrett 2010:247); the Zondervan atlas of the Bible (Rasmussen 2010:231), place the route west of Samos. The Oxford Bible atlas (Curtis 2009:169) and the Harper Collins atlas of Bible history (Pritchard 2008:167), (imprecisely) place the route east of Samos.

7.Utilising the new online digital mapping program, Orbis: The Stanford Geospatia Network Model of the Roman World (www. calculated for the month of May from Chios to Samos. The results indicated a calculated for the month of May from Chios to Samos. The results indicated a
distance of $135 \mathrm{~km}$ which took 0.9 days. A similar route calculated to 'Trogilion Pr' distance of $135 \mathrm{~km}$ which took 0.9 days. A similar route calculated to 'Trogilion $\mathrm{Pr}$ '
displayed $150 \mathrm{~km}$ in one day. Both routes went west of the island. The question also displayed $150 \mathrm{~km}$ in one day. Both routes went west of the island. The question also already begun to follow the lonian coast, then it would have certainly continued on the leeward side of Samos.

8.In response to a question about the preferred sailing route from Chios to Samos, Linford Stutzman, a New Testament scholar who has personally sailed these waters (Stutzman 2006), replied: 'If I were plotting my own course, I would choose the inside route, and I am almost certain that the captain of Paul's boat would have chosen this route' (Linford Stutzman, pers. comm., 23 February 2013). 
Mycale terminated in a promontory called Trogyllium (cf. Strabo Geogr. 14.1.12), a name found in the Byzantine (byz)

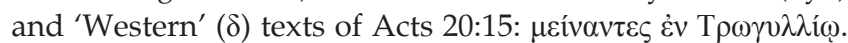
The KJV and NKJV, following the Byzantine text, add here: 'tarried ("stayed" NKJv) at Trogyllium'. Whether this reading is original is unknown. Bruce (1979:410), commenting on the inclusion of Trogyllium, writes: 'The additional words ... are not likely to have been interpolated and may have fallen out of the Alexandrian textual tradition. ${ }^{\prime 9}$ Therefore it is noteworthy that a significant geographical reference is found here. With his ship becalmed, the captain found anchorage at a nearby harbour called Trogyllium. This portage still exists at a desolate spot on the southwestern tip of the modern Dilek Peninsula in Turkey. ${ }^{10}$ The failure of the winds would have delayed the arrival of the apostolic party at Miletus by perhaps half a day. Of course, this presents an irony in the text. Whilst Paul is hurrying toward Jerusalem, the forces of nature slow him down.

\section{The Gulf of Latmus}

On the following day Paul's ship continued its journey to Miletus and entered the Gulf of Latmus (Figure 2). This gulf separating Miletus from Mycale is strangely absent on all biblical maps of western Asia Minor. A selective review of eight major Bible atlases published since 2006 demonstrates the problem. The IVP atlas of Bible history (Lawrence 2006:161), Carta's new century handbook and atlas of the Bible (Rainey \& Notley 2007:246), National Geographic's The biblical world (Isbouts \& Chilton 2007:311), HarperCollins atlas of the Bible (Pritchard 2008:167), Oxford Bible atlas (Curtis 2009:261), New Moody Bible atlas (Beitzel 2009:261), Zondervan atlas of the Bible (Rasmussen 2010:231) and Crossway ESV Bible atlas (Currid \& Barrett 2010:247) all depict the coast of 1st-century Asia Minor as it exists today. This omission is unfortunate because the Gulf of Latmus has been represented on maps such as W.M. Calder and G.E. Bean's standard 'A classical map of Asia Minor'. ${ }^{11}$ The Calder and Bean map has now been superseded by the regional maps found in the Barrington atlas of the Greek and Roman world (Talbert 2000). Whilst the large-scale Ephesus area map 61R shows the modern coastline, an enlarged inset on 61L shows the Gulf of Latmus and its surrounding area from the archaic to Roman periods (Talbert 2000). The Gulf of Latmus is also represented in many of the detailed maps of the western coast of Asia Minor in Brill's New Pauly historical atlas of the ancient world (Wittke, Olshausen \& Szydlak 2010). Three of the four maps on the Pergamene kingdom of the Attalids show the gulf (p. 125). Unfortunately the larger-scale maps in the New Pauly such as

$9 . H a e n c h e n(1971: 53)$, on the other hand, writes: 'Since the redactor held it unlikely that the ship spent the night in the roads instead of putting in at the nearest harbor, he emended accordingly.' Marshall (1980:328) adopts a pragmatic approach: 'whether authentic or not, [the reading] probably describes what the travellers actually did.'

10.This cove is called Port St Paul in Denham's book of charts of the Aegean Sea (1970:123-124). He writes, 'The origin of the name ... is obscure, but by tradition St Paul on one of his voyages down the Anatolian coast put in here for a night's shelter to rest the oarsmen.' This author tried to reach this harbour in the summer of 2010 , but the area is a military zone and the road there is passable only with a four-wheel drive vehicle.

11.This map, dating from 1958 and now out of print, was based on J.G.C. Anderson's 'Map of Asia Minor' (1903), which also showed the gulf. The primary reason for this cartographic error is that modern map makers and atlas authors or editors are unaware of the changed coastline. Hopefully Bible atlases published in the future will show the area around Miletus as it was in the 1st century. those found on pages 161, 183 and 197 only show the modern coastline. Maps in works by specialists on Asia Minor show the Gulf of Latmus; for example, see Maps 1 and 2 in Ma (1999:xviii-xix).

What has happened over the centuries to change the coastline? Because of minimal tidal action in the Aegean Sea, the mouths of rivers in western Asia Minor have progressively silted up. Best known is that of the Cayster (Kücük Menderes) River, which eventually caused the city of Ephesus to become landlocked. The next river system to the south was the Meander (Büyük Menderes). Greaves (2002:6-7) writes, 'The mouth of the Büyük Menderes has moved progressively southwards and eastwards towards the Aegean due to the large amount of silt being carried down from the mountains.' Various hydrological survey teams have been working near Miletus to document this process, called alluviation or progradation. The first of these was conducted in the late 1980s with a resulting publication and map that sought to portray this process (Aksu, Piper \& Konuk 1987:230, Figure 3). ${ }^{12}$ More recently, Brückner, working with other hydrologists and archaeologists, has been conducting extensive research on documenting progradation in the river deltas of western Turkey, such as the Meander. The result has been a number of publications that include new maps on the gulf's progradation based on these field studies. ${ }^{13}$

In antiquity the Gulf of Latmus separated Priene from Miletus. It was named after the mountain situated at its head - Latmus (Beşparmak Dağı, 1367 m). In 500 BCE the gulf extended inland, making Priene and Myus port cities as well. Because of silting, the shoreline moved progressively toward the coast. How fast this progradation occurred is unknown, but by the 1st century CE Priene was landlocked and Myus could only be reached by rowboats. ${ }^{14}$ However, Strabo (Geogr. 14.1.10) states that in the 1st century CE Miletus and Heraclea ad Latmus were still port cities on the gulf. By 500 CE even Miletus was landlocked, and the Gulf of Latmus had disappeared except for its upper portion, now called Bafa Lake (Çamiçi Gölü). ${ }^{15}$

\section{Change of plans and summons to Miletus}

Paul's change of mind and decision to stop in Miletus, despite his hurry to reach Jerusalem, are not explained by the 'we' narrator. Most commentators fail even to speculate concerning this change of plans. ${ }^{16}$ Trebilco (2004:173) appears 12.The map in Greaves' book on lonia (2010:59) is drawn from Aksu's map.

13.The colour map illustrating this section is available in Wikimedia Commons and used with the permission of its creator, Eric Gaba (2009) (User: Sting) http:// commons.wikimedia.org/wiki/File:Miletus_Bay_silting_evolution_map-en.svg. See also the maps in Brückner (2003a:123, 2003b, Figure 1), Müllenhoff et al. (2004: esp. 56, Figure 1) and Brückner et al. (2006: esp. 69, Figure 2), which depict stages of progradation and interact with the earlier studies of Eisma, Erinc, Akuu et al., Erol and Schröder and Bay. There are slight differences in the maps of the Gulf of Latmus that appear in these studies.

14.See the helpful Table 2 in Brückner et al. (2006:68) of the 'Historic and palaeographic changes in Miletus'.

15.A visit to Heraclea ad Latmus (Kapıkırı) today suggests what life was like on the ancient Gulf of Latmus.

16.Barrett (1998:960) does, however, by suggesting that Paul was carrying a considerable sum of money in the Jerusalem collection and perhaps felt safer stopping in Miletus than in Ephesus. 


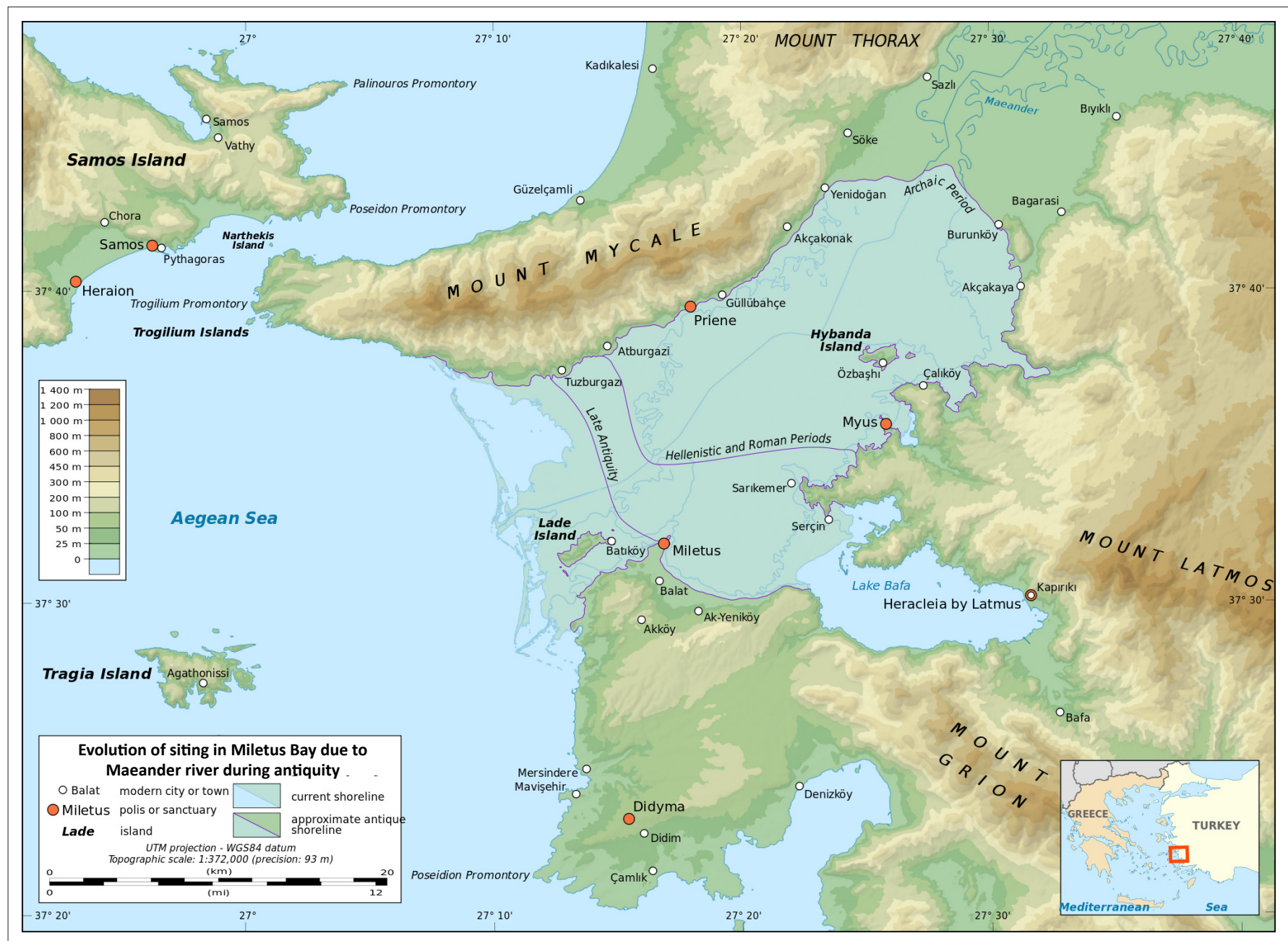

Source: Gaba, E., 2009, Miletus Bay silting evolution, viewed n.d., from http://commons.wikimedia.org/wiki/File:Miletus_Bay_silting_evolution_map-en.svg Wikimedia Commons and used with the permission of its creator, Eric Gaba (User: Sting)

FIGURE 2: Map of the Gulf of Latmus in antiquity.

to be the only commentator to ask: 'If Paul was in a hurry, and so did not visit Ephesus, how do we explain this delay of at least five days?' He (2004:173-174) then suggests four reasons why this was the case and concludes that 'all of these explanations are guesses, and there seems no way of favouring one over the others' ${ }^{17}$ His final reason seems the most probable. Landing at Ephesus' harbour with its direct access to the commercial agora, where the silversmiths were centred, could possibly reignite the situation that had forced Paul to leave Ephesus just months before. Nevertheless, Paul came to feel that he must communicate with the elders of Ephesus one final time because he felt the possibility of death awaited him in Jerusalem (Ac 25:38).

From Miletus Paul sent a messenger across the Gulf of Latmus to Ephesus to summon the elders. Bruce (1990:429) suggests that the messenger was perhaps a member of the church in Miletus. Whilst this suggestion is logical, neither Acts nor Paul's letters specifically mention a Christian community in

17.Trebilco's four 'guesses' are: (1) the fastest boat traveling from Troas was not stopping at Ephesus but at Miletus instead, (2) since delivering the collection to Jerusalem was the primary reason for the journey, this provided a good reason for haste and the avoidance of Ephesus, (3) a visit to Ephesus could hinder his commitment to go to Jerusalem since it might involve protracted delays due to commitment to go to Jerusalem since it might involve protracted delays due to
opposition or the needs of the church there and (4) either he had been banned opposition or the needs of the church there and (4) either he had been banne
from Ephesus or the opposition was so great that he could not return there.
Miletus at this time. ${ }^{18}$ Acts 20:4 names two Asian believers, Tychicus and Trophimus, who were amongst the 'brothers' traveling with Paul to Jerusalem. Later we are told that Trophimus was an Ephesian (21:29), so it is quite probable that he was the messenger dispatched by Paul to bring the elders. ${ }^{19}$ Whether Trophimus also carried a written message to accompany Paul's verbal instructions is unknown. After Paul's abrupt departure from Ephesus and his return to Macedonia and Achaia, the Ephesian elders were perhaps wondering if they would hear from Paul again before he returned to Jerusalem. So it was undoubtedly a pleasant surprise to receive Paul's summons to Miletus for a meeting.

\section{The elders journey to Miletus}

How did the elders return with the messenger 'Trophimus'? The group had the options of travelling by ship or overland from Ephesus. The easiest and fastest mode of travel would

18.Schnabel (2004:1231) is optimistic and believes that Luke's account in Acts 20 'implies that there was a house in Miletus in which Christians could meet, suggesting the existence of a church'. However, the text in Acts never mention that the meeting took place in a building. The men kneeling with Paul in prayer then embracing and kissing him before they proceed directly to the ship (Ac 20:3638 ) suggests rather that the meeting was outdoors, perhaps near one of Miletus'
four harbours. 19.It is this same Trophimus who is later left sick in Miletus by Paul according to
2 Timothy 4:20. 
appear to be by sea for the short voyage to Miletus. However, the elders would first need to locate a coasting vessel traveling south and then negotiate the cost of passage. Of course, they would be at the mercies of the sea breezes to reach their goal. If Paul's ship had been delayed at Trogyllium already, the possibility of another delay would have been in their minds as they pondered which route to take. Bekker-Nielsen (2013) aptly states the dilemma:

For travelers and couriers, on the other hand, road travel had the advantage of predictability. A sea traveller might have to wait days or weeks in port for a ship and a favourable wind. (p. 10)

Given the need to reach Paul promptly, the predictable land route was undoubtedly chosen.

As we have seen, Bible atlases do not help us in interpreting the geographical dynamics involved with this journey. Commentators on this passage, relying on such inexact maps, typically assume that it was an easy journey from Ephesus and thus arrive at faulty conclusions. For example, speculation exists regarding the distances involved. Haenchen (1971:590) approximates a distance of about $51.5 \mathrm{~km}$ as the crow flies, although it is much further by road. Of course, no messenger would go directly over the mountains of Mycale so the distance by air is not particularly helpful. Measurements using Google Earth together with the Barrington atlas (Talbert 2000) suggest a road distance of approximately $72 \mathrm{~km}$ between Ephesus and Miletus. Factored into that figure is a crossing of the Gulf of Latmus by ferry, a distance of approximately $11 \mathrm{~km}$. It also is unlikely that the elders would have walked around the Gulf of Latmus. Strabo (Geogr. 14.1.9), in describing the distances between the cities of Miletus, Heraclea and Pyrrha, contrasts the short distances by water with the much longer ones following the coast.

Departing Ephesus, the group would have passed through the Magnesian Gate at the city's southeastern perimeter. Dating from the second half of the 1st century BCE, the gate served as the exit point to Ephesus's sister city Magnesia ad Maeandrum, $24 \mathrm{~km}$ to the southeast. Because this was also the road that led eastward through the Meander valley - the great southern highway that eventually led to Tarsus and Antioch on the Orontes - there would be many travellers on it. The Magnesian Gate also served as the entry point into Ephesus for the Sacred Way from the nearby Temple of Artemis. The elders might have passed one of the regular processionals coming from the Artemisium that also included worship to the Roman emperors through the imperial cult (Rogers 1991:86, 196; Scherrer 2000:66-68). After descending into the plain, the elders could look back and see the 127 columns of the Temple of Artemis rising nearby to their left..$^{20}$ Three kilometres southeast of the Magnesian Gate, the road passed through the Marnas valley beneath a monumental two-story, triple-arched aqueduct built in 4-14 CE through the benefaction of an Ephesian noble named Pollio. The well-preserved bilingual Greek-Latin dedicatory inscription states that 'C. Sextillius Pollio erected this structure with Biblical Turkey (Wilson 2010). his wife Ofillia Bassa and his stepson C. Ofillius Proculus from their own funds in honor of Augustus, Tiberius, and the Ephesian demos'. The aqueduct (Figure 3) was part of the Aqua Throessitica system that supplied Ephesus with water (Scherrer 2000:228-229).

After climbing out of the watershed of the Cayster River, the elders would encounter a milestone telling them they had travelled five Roman miles $(\varepsilon ;$ ca. $8 \mathrm{~km}$ ) from Ephesus. The milestone (Figure 4) carried the name of Manius Aquillius, the first governor of Asia. He built a road from Ephesus to Laodicea where it met a branch from Pergamum, which then continued south-eastward to its terminus at Side. This road was built soon after the province was incorporated into the Roman Empire in 129 BCE. ${ }^{21}$ After passing through a lush forested plateau southeast of modern Çamlık, they began their descent into the Meander valley.22

Soon after walking out on the valley floor, the elders would encounter the aqueduct system of Magnesia ad Maeandrum. The Roman road paralleled this wonder of ancient engineering for several kilometres and led them into the city. Magnesia had all the typical features of a Greco-Roman city, but she was especially known in antiquity as the home of the temple of Artemis Leucophryne (Figure 5) ('with white eyebrows'). Magnesia was linked with Ephesus in that they both possessed important temples to Artemis. The elders would undoubtedly be impressed by the size of the temple, the fourth largest Hellenistic temple in Asia Minor. ${ }^{23}$ West of the temple was an elaborate altar to Artemis, believed to be a smaller model of the famous altar of Zeus in Pergamum (Bingöl 2007:77-81). Whether there was a Christian community at this time is unknown, but it is likely that Paul travelled to and through the city during his time in Ephesus and preached the gospel there. Ignatius addressed a letter to the Christians in Magnesia in the early 2nd century $\mathrm{CE}$ as well as those in nearby Ephesus and Tralles. The three Christian communities undoubtedly shared a common spiritual history so they all likely date to the middle of the 1st century. ${ }^{24}$ Depending on when the elders left Ephesus, Magnesia might have been their resting point for the first day.

The next city was Priene, $31 \mathrm{~km}$ ahead. After Magnesia, the elders began to follow the road in the Meander River valley along the southern base of Mycale and the northern shore of Latmus. The acropolis of this important Ionian city would have loomed before them in the distance. Priene was noted for its famous temple of Athena Polias, the city's most important

21.The distance on this Republican milestone found at Çamlik clearly indicates that the road's caput viae was Ephesus. The milestone is now displayed near the lower gate at Ephesus (French 1988:169-70, 2012:10, 36)

22.A century later the procurator, $M$. Caecilius Numa, oversaw the engineering of a rock-cut road called the Trachon that descended from this pass. Thonemann (2011:104, n. 11) calls it 'one of the most impressive engineering works in western Anatolia'.

23.For a detailed discussion of the temple with accompanying illustrations, see Bingöl (2007:53-76).

24.Schnabel (2004: 1233-1235) agrees with this assessment, suggesting that whilst Paul and his coworkers were active in Ephesus, churches in Priene, Magnesia ad Maeandrum and Tralles were founded. 


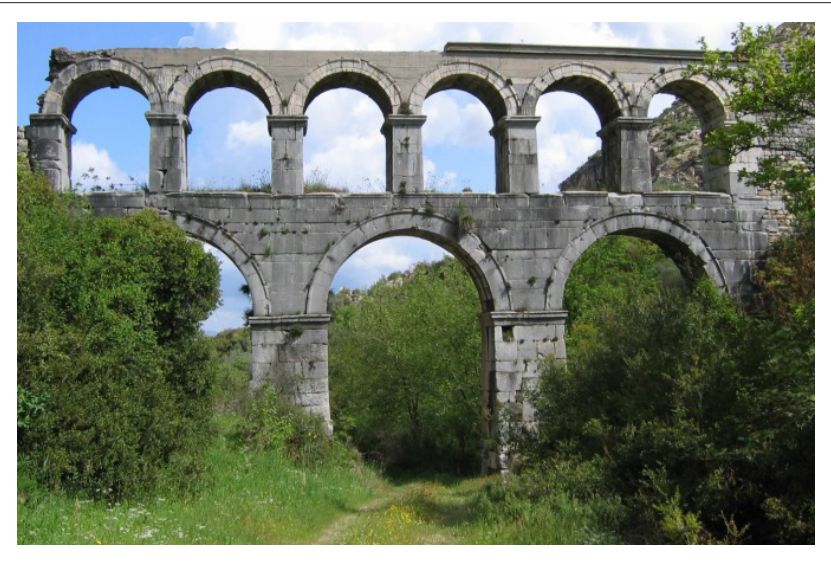

Photo: By Dr Mark Wilson.

FIGURE 3: The Pollio aqueduct.

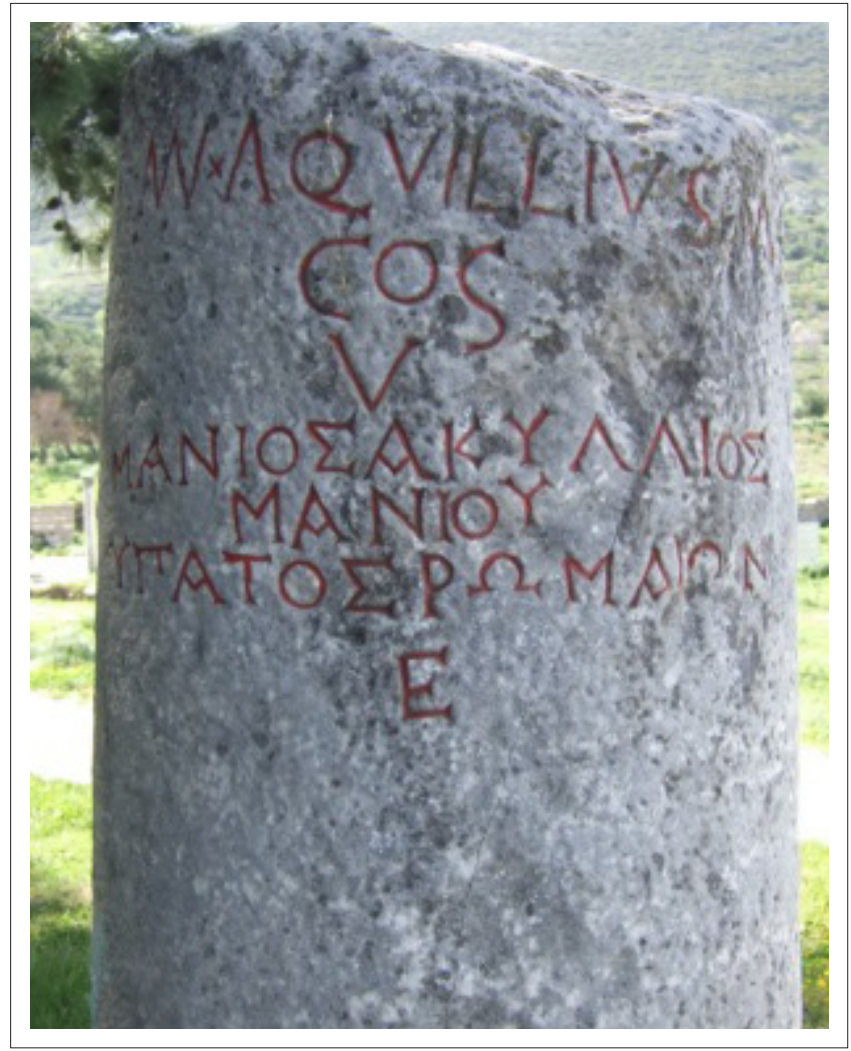

Photo: By Dr Mark Wilson.

FIGURE 4: The Manius Aquillius milestone.

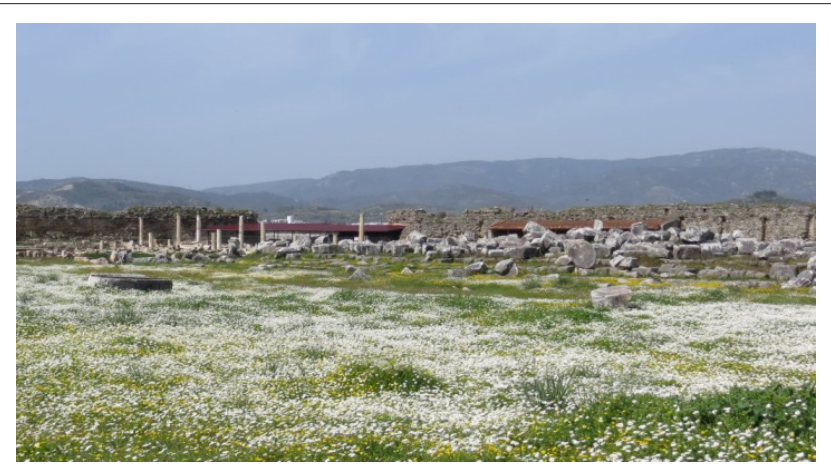

Photo: By Dr Mark Wilson.

FIGURE 5: The remains of the temple of Artemis in Magnesia. public building. Designed by Pythius, the architect for the mausoleum at Halicarnassus, this hexastyle and peripteral temple with 11 columns on its long sides served as a model for Ionic temple architecture throughout the Greco-Roman world (Figure 6). By the middle of the 1st century Priene no longer had access to the Gulf of Latmus because of silting. Instead, Priene's port is thought to have been located about $6 \mathrm{~km}$ west near the modern village of Atburgazi. ${ }^{25}$ Depending on the time, the elders might have stopped for rest and a meal in Priene before continuing their journey.

Although Miletus was distantly visible across the gulf, the elders now encountered the final physical obstacle preventing their reunion with Paul - an 11-km stretch of water. Although no literary texts mention a ferry shuttling travellers across the Gulf of Latmus to Miletus, such a mode of transport must have existed. ${ }^{26}$ How long the elders waited for such a ferry, we do not know. But at some time, after 2 long days of travel, they would have finally arrived at Miletus, perhaps disembarking at its Lion Harbour (Figure 7).

\section{A walk on the Sacred Way}

Various time frames have been suggested for Paul's wait at Miletus. Hemer (1989:125), following Bruce (1990:429), thinks only 2 or 3 days were needed to make the round-trip journey. They arrive at this by estimating the distance by boat and road to be only $48 \mathrm{~km}$. Dupont (1962:27) estimates a wait of 3 days. Barrett (1998:960) more realistically suggests that Paul would be 'obliged to spend more than 5 or 6 days in Miletus'. Haenchen (1971:590) likewise suggests that the messenger may have taken 2 days to travel from Miletus to Ephesus and slightly longer for the party's return to Miletus. These estimates lack any discussion as to how this waiting time was estimated, which this study has attempted to do in the previous paragraphs. ${ }^{27}$ As we have seen, the distance by land and water between Miletus and Ephesus was approximately $72 \mathrm{~km}$, so a minimum of 4 long days of traveling was required for the messenger to return to Miletus with the elders (Figure 8).

As Paul waited for the Ephesian elders - and if he took a walking tour of the city like he did in Athens (cf. Ac 17:16-17, 23) - he would certainly have seen Miletus's noted sanctuary for Apollo Delphinius (Figure 9) near the Lion Harbour. In front of the Delphinion, one of the most famous sacred walks in antiquity started. It ran $16 \mathrm{~km}$ southward to the sanctuary of Apollo in Didyma, one of the three main oracle sanctuaries in the Aegean region. In his stroll around Miletus, Paul would have walked on the beginning of this Sacred Way and observed inscriptions mentioning the Didymean prophets. ${ }^{28}$

25 . For the possible connection of this to the port of Naulochus, see Rumscheid and Koenigs (1998:15-17)

26.Strabo (Geogr. 12.8.19) refers to the presence of ferries upstream on the Meander River. See the photograph in Thonemann (2011:309) of a ferry on the lower Meander near Myus taken by the excavators of Priene, Wiegand and Schrader, in the late 1800 s.

27.Barrett (1998:960) does hint at this possibility: 'he [Luke] might ferry the Ephesian elders across in order to provide a partly Ephesian audience.'

28. Herda (2006:447-461) has extensively researched the Sacred Way that linked Miletus to Didyma and discussed the relationship between Apollo Delphinios and Apollo Didymeus along with Miletus and Didyma. An English summary of his work is now available (Herda 2011). 


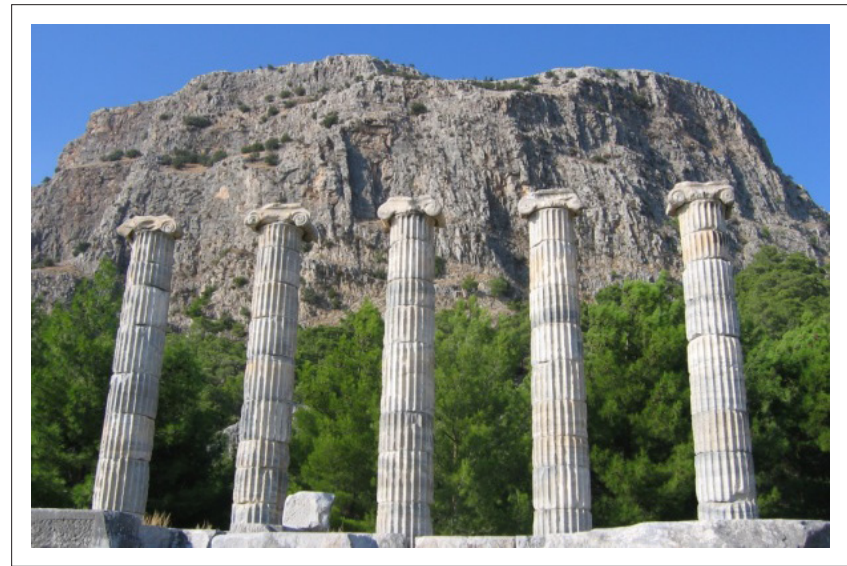

Photo: By Dr Mark Wilson.

FIGURE 6: The remaining columns of the temple of Athena and the acropolis of Priene.

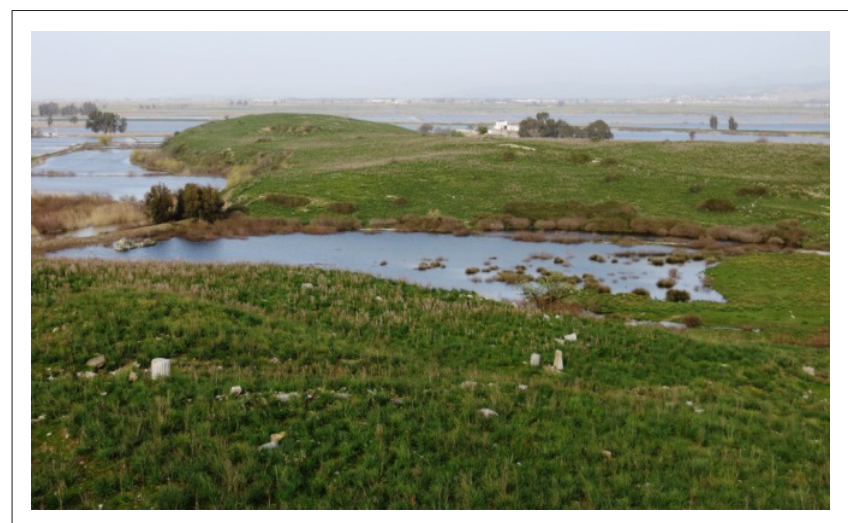

Photo: By Dr Mark Wilson.

FIGURE 7: The Lion Harbour of Miletus.

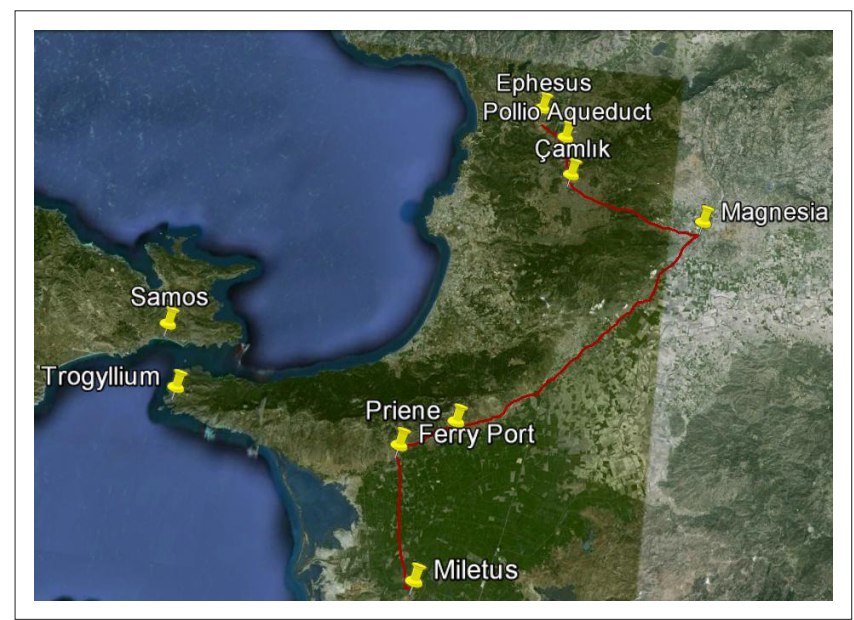

Source: Courtesy Google Earth

FIGURE 8: The route of the elders from Ephesus to Miletus.

Was Paul curious enough to make the round-trip to see the Didymeion? He certainly had the time to make the journey.

Some readers of Acts might have recognised the irony in this text: Miletus, the beginning of the Sacred Way to the Didymeion, now became the terminus of a walk taken by the Ephesian elders to meet the apostle of a very different sacred Way! Paul's reference to the prophetic words given him by

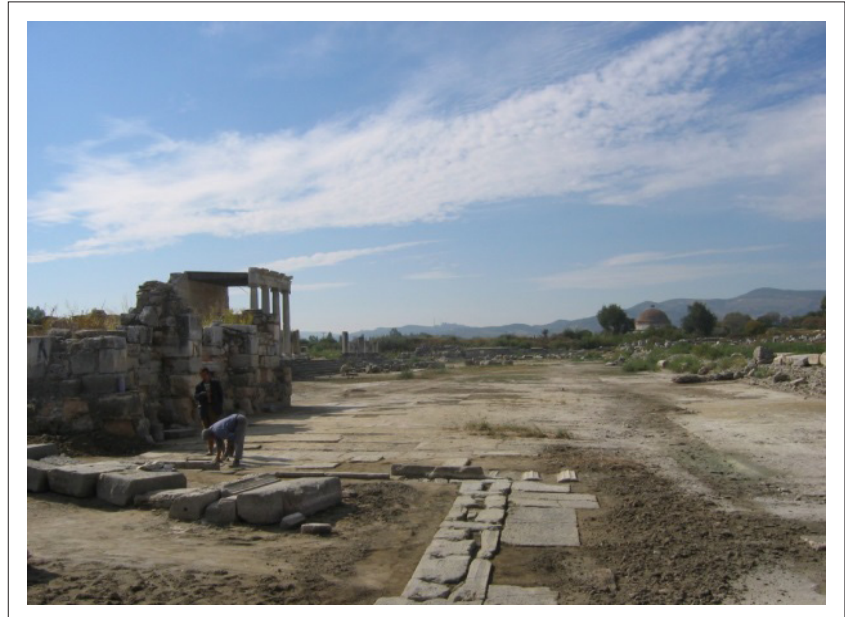

Photo: By Dr Mark Wilson.

FIGURE 9: The Delphinion looking southward at the beginning of the Sacred Way in Miletus.

the Spirit (Ac 20:23) likewise placed his understanding of divine prophecy at odds with what was practiced at Didyma. Whilst the nascent Christian movement began in the shadow of the Apollo oracles, its steady growth as a prophetic movement soon brought it into conflict with them (Wilson 2008:172-175). Thus Paul's stop at Miletus portended a clash of prophetic voices that would end with the legalisation of Christianity and the demise of the Apollo cults in the 4th century. ${ }^{29}$

\section{The Narratee and first readers}

Finally, we might ask whether the geographical and historical insights drawn from this text using an Annaliste reading would have been recognisable to the original narratee Theophilus (Ac 1:1) and other first readers. Alexander (1999:163) observes this about Acts: 'This is a communication dependent on the conscious choice of its writer and written for the needs of a particular reader.' Granting that some literary dedications in antiquity existed as a social fiction, it is assumed that Theophilus was a real reader located in Rome or some other major city (Alexander 1999:163-164). In his explication of the significance of Theophilus as a type of the first readers, Creech (1990) observes:

Theophilus is assumed to be broadly familiar with the Roman world. The narrator regularly mentions place names without explanation ... He is broadly familiar with the geography of the Empire. (pp. 116, 122)

What today's audience generally misses in this pericope, Theophilus and other first readers would undoubtedly have understood by virtue of their education and experience.

The first readers also had a literary background foreign to most of today's readers. For example, Acts 20:15-16 mention four of the twelve cities that comprised the Ionian League Chios, Samos, Miletus and Ephesus. ${ }^{30}$ Hence Luke's account does not merely include coastal cities; rather, it refers to ones 29.The others were at Delphi and Claros. I discussed this conflict in 'The Rise of the Christian Oracles in the Shadow of the Apollo Cults' (Wilson 2008:162-175).

30.The other eight cities comprising the Ionian dodekapolis were Phokaia, Erythrai, Klazomenai, Teos, Lebedos, Kolophon, Priene, and Myus. After 650 BCE Smyrna was added (Greaves 2010:96). 
that had great significance in antiquity. Herodotus (Hist. 1.142) mentions the league and the cities that comprised it. The 1st-century CE geographer Strabo (Geogr. 14.1.2-4) likewise discusses the league and the foundation myths associated with its cities. ${ }^{31}$ Given the prominence accorded to the Ionians and their history by these writers separated by centuries in time, it is highly likely that the first readers as educated Greek-speaking Gentiles would have recognised the historical connections amongst these cities and their significant place in the book of Acts.

\section{Conclusion}

Our Annaliste reading has produced several fresh insights into the text of Acts 20:15-18a. Building on Greaves' observation that landscape and geography are a critical background for the reading of a text, let us seek to elucidate those insights:

- Paul's travel by sea included visits to notable Ionian cities. However, he decided to skip Ephesus in order to reach Jerusalem by Pentecost.

- A variant reading in the Byzantine and 'Western' texts gives a credible description of a probable weather delay that left Paul's ship temporarily becalmed at Trogyllium.

- The failure to depict the Gulf of Latmus in Bible atlases has produced incorrect calculations related to Paul's journeys in western Asia Minor.

- A land route taken by the Ephesian elders through important centres of Greco-Roman culture has been suggested; its distance has been underestimated by commentators on Acts.

- Paul's waiting time in Miletus has likewise been underestimated, which would have given him time not only to tour the city but also to visit the Apollo temple at Didyma.

- Paul's emphasis on prophecy in his speech in Miletus was probably influenced by the city's geographical proximity to the oracle at Didyma.

- Since Miletus is the origination point of a famous Sacred Way in antiquity, the walk of the elders to Miletus portends a contrast with a new holy Way.

The emphasis of the Annaliste reading on geography and environment has helped to elucidate several fresh insights in this text. Thus, the methodology might also prove useful in exegeting other texts in the book of Acts.

\section{Acknowledgement Competing interests}

The author declares that he has no financial or personal relationship(s) which may have inappropriately influenced him in writing this article.

\section{References}

Aksu, A.E., Piper, D.J.W. \& Konuk, T., 1987, 'Quarternary growth patterns of Büyük Menderes and Küçük Menderes deltas, Western Turkey', Sedimentary Geology 52, 227-250. http://dx.doi.org/10.1016/0037-0738(87)90063-7

31.Although writing a century later, Pausanius (Descr.7.2.3-5.6) draws upon general knowledge in his extensive discussion of the cities of lonia.
Alexander, L.C., 1999, 'What if Luke had never met Theophilus', in J. Cheryl Exum (ed.), Virtual history and the Bible, pp. 161-170, Brill, Leiden.

Barrett, C.K., 1998, Acts 15-18, vol. 2, T \& T Clark, London-New York.

Beitzel, B.J., 2009, The New Moody atlas of the Bible, Moody, Chicago. PMid:19338049

Bekker-Nielsen, T., 2013, 'Land transport in Cyprus', in M.L. Lawall \& J. Lund (eds.), The transport amphorae and trade of Cyprus, pp. 10-17, Aarhus University Press, Aarhus.

Bingöl, O., 2007, Magnesia on the Meander: An archaeological guide, Homer Kitabevi, Istanbul.

Braudel, F., 1972, The Mediterranean and the Mediterranean world in the age of Philip II, University of California Press, Berkeley.

Bruce, F.F., 1979, The book of the Acts, Eerdmans, Grand Rapids.

Bruce, F.F., 1990, The Acts of the apostles, 3rd edn., Eerdmans, Grand Rapids.

Brückner, H., 2003, 'Delta evolution and culture - aspects of geoarchaeological research in Miletos and Priene', in G.A. Wagner, E. Pernicka \& P. Uerpmann (eds.), Troia and the Troad: Scientific approaches, pp. 121-144, Springer, Berlin. http:// dx.doi.org/10.1007/978-3-662-05308-9_9

Brückner, H., Müller, K.H., Müllenhoff, M. \& Uncu, L., 2003, 'Modelling coastal change in space and time: The example of the Büyük Menderes delta plain in Turkey', Puglia 2003 - Final Conference Project IGCP 437, viewed 04 July 2012, from http:// www.igcp437finalconference.unisalento.it/AbstractBook/Bruckner51_52.pdf

Brückner, H., Müllenhoff, M., Gehrels, R., Herda, A., Knipping, M. \& Vött, A., 2006, 'From archipelago to floodplain - geographical and ecological changes in Miletus and its environs during the past six millennia (Western Anatolia, Turkey)', Zeitschrift für Geomorphologie N.F., suppl. ser. 142, 63-83, viewed 08 July 2012, from http://www.deucbs.com/igcp2009/eng/BruecknerEtAl_Miletus_Part1.pdf; http://www.deucbs.com/igcp2009/eng/BruecknerEtAl_Miletus_Part2.pdf

Creech, R., 1990, 'Most excellent narratee: The significance of Theophilus in LukeActs', in N.H. Keithley (ed.), With steadfast purpose: Essays on Acts in honor of Henry Jackson Flanders, Jr., pp. 107-126, Baylor University Press, Waco.

Currid, J.D. \& Barrett, D.P., 2010, Crossway ESV Bible atlas, Crossway, Wheaton.

Curtis, A., 2009, The Oxford Bible atlas, Oxford University Press, New York.

Denham, H.M., 1970, The Aegean, Charles Scribner's Sons, New York.

Dupont, J., 1962, Le discours de Milet, testament pastoral de saint Paul (Actes 20:1836) [The Discourse at Miletus, A Pastoral Testament of Saint Paul (Acts 20:18-36)] Éditions du Cerf, Paris.

French, D.H., 1988, Roman roads and milestones of Asia Minor, Fasc. 2: An interim catalogue of milestones, Part 1, BAR International, Oxford.

French, D.H., 2012, Roman roads and milestones of Asia Minor, Vol. 3 Milestones, Fasc. 3.1 Republican, British Institute at Ankara, Ankara, viewed 08 October 2012, from http://www.biaa.ac.uk/home/images/stories/rrmam\%20vol.\%203\%20 milestones.pdf

Gaba, E., 2009, Miletus Bay silting evolution, viewed n.d., from http://commons. wikimedia.org/wiki/File:Miletus_Bay_silting_evolution_map-en.svg

Greaves, A.M., 2002, Miletos A history, Routledge, London \& New York.

Greaves, A., 2010, The land of Ionia: Society and economy in the archaic period, Wiley Blackwell, West Sussex.

Haenchen, E., 1971, The Acts of the Apostles, Westminster, Philadelphia.

Hemer, C., 1989, The book of Acts in its Hellenistic setting, Mohr Siebeck, Tübingen. PMid:2760058

Herda, A., 2006. Der Apollon-Delphinios-Kult in Milet und die Neujahrsprozession nach Didyma. Ein neuer Kommentar der sog. Molpoi-Satzung, Philipp von Zabern, Mainz.

Herda, A., 2011, 'How to run a state cult: The organization of the cult of Apollo Delphinios at Miletos', in J. Wallensten \& M. Haysom (eds.), Current approaches to religion in ancient Greece, An international symposium, 17-19 April 2008, pp. to religion in ancient Greece, An international symposium, 17-19 April 2008, pp. 57-93, Swedish Institute/British School at Athens, Athens, viewed 23 September
2012, from http://uni-tuebingen.academia.edu/AlexanderHerda/Papers/688862/ 2012, from http://uni-tuebingen.academia.edu/AlexanderHerda/Papers/688862/ Delphinios_in_Miletos

Isbouts, J.-P. \& Chilton, B., 2007, The Biblical world: An illustrated atlas, National Geographic, Washington, DC.

Knapp, A.B., 1992, 'Archaeology and annales: Time, space, and change', in A.B. Knapp (ed.), Archaeology, Annales, and Ethnohistory, pp. 1-22, Cambridge University (ed.), Archaeology, Annales, and Ethnohistory, pp. 1-22, Cambridge University
Press, Cambridge. http://dx.doi.org/10.1017/CBO9780511759949.002, Press, Camb
PMid:1373058

Lambrianides, K. \& Spencer, N., 2007, The Madra River delta: Regional studies on the Aegean coast of Turkey, British Institute of Archaeology, Ankara.

Lawrence, P., 2006, The IVP atlas of Bible history, Inter-Varsity, Downers Grove, IL.

Ma, J., 1999, Antiochus III and the cities of western Asia Minor, Oxford University Press, Oxford.

Marshall, I.H., 1980, The Acts of the Apostles, Eerdmans, Grand Rapids.

Müllenhoff, M., Handl, M., Knipping, M.M. \& Brückner, H., 2004, 'The evolution of Lake Bafa (Western Turkey) - sedimentological, microfaunal and palynological results', in G. Schernewski \& T. Dolch (eds.), Geographie der Meere und Küsten Coastline Reports 1, pp. 55-66, viewed 19 July 2012, from http://databases. eucc-d.de/files/documents/00000342_AMK2004_Artikel_Muellenhoff.pdf

Orbis: The Stanford Geospatial Network Model of the Roman World, computer software, viewed 27 February 2013, from http://orbis.stanford.edu/ 
Pritchard, J.B., 2008, HarperCollins atlas of Bible history, HarperCollins, San Francisco. Rainey, A.F. \& Notley, R.S., 2007, Carta's New Century handbook and atlas of the Bible, Carta, Jerusalem.

Rasmussen, C., 2010, The Zondervan atlas of the Bible, Zondervan, Grand Rapids. Rogers, G.M., 1991, The sacred identity of Ephesos: Foundation myths of a Roman city, Routledge, London \& New York.

Rumscheid, F. \& Koenigs, W., 1998, Priene: A guide to the 'Pompeii of Asia Minor, Ege Yayınları, Istanbul.

Schnabel, E., 2004, Early Christian mission, vol. 2, InterVarsity, Downers Grove, IL. Scherrer, P. (ed.), 2000, Ephesus the new guide, Ege Yayınları, Istanbul.

Stutzman, L., 2006, Sailing Acts, Good Books, Intercourse, PA.

Talbert, R.J.A. (ed.), 2000, Barrington atlas of the Greek and Roman world, Princeton University Press, Princeton.
Thonemann, P., 2011, The Maeander valley: A historical geography from antiquity to Byzantium, Cambridge University Press, Cambridge. http://dx.doi.org/10.1017/ CB09780511974847

Trebilco, P.R., 2004, The early Christians in Ephesus from Paul to Ignatius, Mohr Siebeck, Tübingen.

Walton, S., 2007, Leadership and lifestyle: The portrait of Paul in the Miletus speech and 1 Thessalonians, Cambridge University Press, Cambridge.

Wilson, M., 2008, 'The rise of the Christian oracles in the shadow of the Apollo cults', Ekklesiastikos Pharos 90, 162-175.

Wilson, M., 2010, Biblical Turkey: A guide to the Jewish and Christian sites of Turkey, Ege Yayınları, Istanbul.

Wittke, A.-M., Olshausen, E. \& Szydlak, R. (eds.), 2010, New Pauly historical atlas of the ancient world, Brill, Leiden/Boston. 